
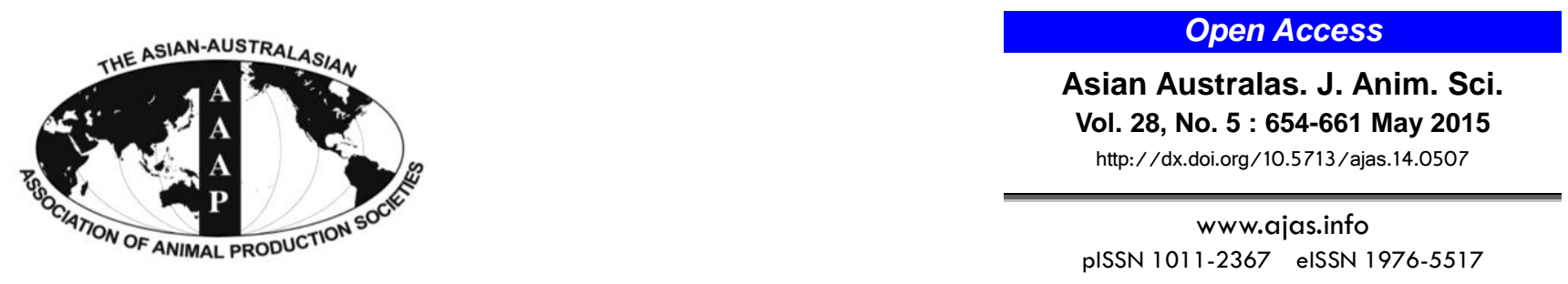

\title{
Prediction of Digestible and Metabolizable Energy Content of Rice Bran Fed to Growing Pigs
}

\author{
C. X. Shi, Z. Y. Liu, M. Shi, P. Li, Z. K. Zeng, L. Liu, C. F. Huang, Z. P. Zhu ${ }^{1}$, and D. F. Li* \\ State Key Laboratory of Animal Nutrition, Ministry of Agriculture Feed Industry Centre, \\ China Agricultural University, Beijing 100193, China
}

\begin{abstract}
Two experiments were conducted to determine the digestible energy (DE) and metabolizable energy (ME) content of 19 rice bran samples and to develop prediction equations for DE and ME based on their chemical composition. The 19 rice bran samples came from different rice varieties, processing methods and regions. The basal diet was formulated using corn and soybean meal (74.43\% corn and $22.91 \%$ soybean meal and $2.66 \%$ vitamins and minerals). The 19 experimental diets based on a mixture of corn, soybean meal and $29.2 \%$ of each source of rice bran, respectively. In Exp. 1, 108 growing barrows $(32.1 \pm 4.2 \mathrm{~kg})$ were allotted to 1 of 18 treatments according to a completely randomized design with 6 pigs per treatment. The treatment 1 was the control group which was fed with basal diet. The treatments 2 to 18 were fed with experimental diets. In Exp. 2, two additional rice bran samples were measured to verify the prediction equations developed in Exp. 1. A control diet and two rice bran diets were fed to 18 growing barrows $(34.6 \pm 3.5 \mathrm{~kg})$. The control and experimental diets formulations were the same as diets in Exp. 1. The results showed that the DE ranged from 14.48 to 16.85 (mean 15.84) MJ/kg of dry matter while the ME ranged from 12.49 to 15.84 (mean 14.31) MJ/kg of dry matter. The predicted values of DE and ME of the two additional samples in Exp. 2 were very close to the measured values. (Key Words: Chemical Composition, Digestible and Metabolizable Energy, Growing Pigs, Prediction Equations, Process Method, Rice Bran)
\end{abstract}

\section{INTRODUCTION}

Rice bran is a by-product of rice grain production consisting primarily of the outer layers of the grain (Campabadal et al., 1976). The bran is removed during the process of milling to produce white rice for human consumption (Saunders, 1990). It usually includes the pericarp, seed coat and aleurone, as well as most of the germ (Kaufmann et al., 2005). Rice bran has highly available energy, and is generally economical. It is usually used in swine diets because it is widely grown in the East and South East of Asia. There are 40 to 45 million tonnes of rice bran produced annually (David, 1994).

Rice bran had received attention as a source of oil for human consumption (Chris et al., 1985). Some studies had

\footnotetext{
* Corresponding Author: D. F. Li. Tel: +86-10-6273-3588, Fax: +86-10-6273-3688, E-mail: defali@mafic.ac.cn

${ }^{1}$ The New Hope Liuhe Co. Ltd. Chengdu 610063, China.

Submitted Jul. 10, 2014; Revised Sept. 24, 2014; Accepted Nov. 23, 2014
}

been conducted to examine the feasibility of using rice bran as an ingredient in poultry (Hussein and Kratzer, 1982; Sayre et al., 1987; Warren and Farrell, 1990) and swine (Warren and Farrell, 1990). However, rice bran originated from different rice cultivars and grown environmental conditions may differ widely in chemical composition. Previous studies also indicated that different milling operations may affect the chemical composition of rice bran (Majun and Payne, 1977; Serra et al., 1983; Kaufmann et al., 2005).

Because of the large quantity of rice bran produced throughout the world, it is important to determine not only its chemical composition, but also the variation in chemical composition arising from different varieties and processing methods. The hypothesis for this study was that the rice bran came from different rice varieties, processing methods and regions would had different digestible energy (DE) and metabolizable energy (ME) content because their variable chemical composition. Therefore, the object of this study was conducted to determine the DE and ME content of 17 
rice bran samples and then developed prediction equations for DE and ME based on their chemical composition.

\section{MATERIALS AND METHODS}

All the protocols used in these experiments were approved by the Institutional Animal Care and Use Committee of China Agricultural University (Beijing, China). The two experiments were conducted in the Metabolism Laboratory in the Swine Nutrition Research Center of the Ministry of Agriculture Feed Industry Centre (Chengde, Hebei Province, China).

\section{Rice bran samples collection}

Nineteen rice bran samples (approximately $300 \mathrm{~kg}$ per sample) were collected from eleven provinces around China. In order to make the samples representative and increase the variation in the chemical composition of the rice bran used in these experiments, we conducted a survey and investigated more than 50 rice milling plants in China before collecting the samples. We found that the varieties, processing methods and regions had a great influence on quality of rice bran. So the 19 rice bran samples were obtained from different rice varieties, processing methods and regions (Table 1).

Each sample was taken at the rice milling machine when it was working, then sealed, and immediately transported by truck to the laboratory. All samples were stored at $-18^{\circ} \mathrm{C}$ for further analysis and diet formulation. Before the start of the experiments, rice bran sub-samples were collected and analyzed for chemical composition
(Table 2). Samples collecting and experiments were conducted in winter to avoid spoilage (The highest ambient temperature was $10^{\circ} \mathrm{C}$ ).

\section{Experimental design}

All pigs were Duroc $\times$ Landrace $\times$ Large White crossbred barrows. The pigs were placed in individual stainless steel metabolism cages $\left(1.4 \times 0.45 \times 0.6 \mathrm{~m}^{3}\right)$ on concrete slatted floors, in temperature controlled-rooms $\left(22 \pm 1.5^{\circ} \mathrm{C}\right)$. All pigs remained healthy during the experiments and consumed their diets readily. The daily ration allowance was equivalent to $4 \%$ of the body weight at the beginning of the experiments (Adeola, 2001). The daily ration was divided into two equal amounts, and fed at 0830 and $1530 \mathrm{~h}$ in mash form. The feeding level was progressively increased for the first two days in order to reach fixed intakes. Water was provided ad libitum through a nipple drinker. The amount of feed supplied each day was recorded as well as any feed refusals and spillages.

The difference approach and total collection method were used to measure the DE and ME of rice bran. The basal diet was formulated using corn and soybean meal (74.43\% corn and $22.91 \%$ soybean meal and $2.66 \%$ vitamins and minerals). The experimental diets were formulated to contain $29.2 \%$ rice bran which replaced $30 \%$ of the corn and soybean meal in the basal diet. In Exp. 1, 108 growing barrows $(32.1 \pm 4.2 \mathrm{~kg})$ were allotted to 1 of 18 treatments according to a completely randomized design with 6 pigs per treatment. The treatment 1 was a control group which fed with basal diet. The treatments 2 to 18 were experiments groups which were fed with experimental

Table 1. Rice bran sources and milling methods of the 19 rice bran samples used in experiments 1 and 2

\begin{tabular}{|c|c|c|c|}
\hline Province & Rice varieties & Milling method $^{1}$ & Enterprise scale \\
\hline Anhui 1 & Japonica & 1 sand roller and 3 iron rollers & Medium-sized private enterprise \\
\hline Anhui 2 & Indica & 1 sand roller and 3 iron rollers & Medium-sized private enterprise \\
\hline Anhui 3 & Indica hybrid & 1 sand roller and 1 iron roller & Large-sized private enterprise \\
\hline Guangxi & Late Indica & 3 iron rollers & Small-sized private enterprise \\
\hline Henan & Late long-grain Indica & 1 sand roller and 2 iron rollers & Large-sized private enterprise \\
\hline Hubei 1 & Late long-grain Indica & 1 sand roller and 3 iron rollers & Large state-owned enterprise \\
\hline Hubei 2 & Indica & 2 sand rollers and 1 iron roller & Large state-owned enterprise \\
\hline Heilongjiang 1 & Japonica & 1 sand roller and 3 iron rollers & Medium-sized private enterprise \\
\hline Heilongjiang 2 & Japonica & 1 sand roller and 3 iron rollers & Small-sized private enterprise \\
\hline Jilin & Big grain Japonica & 1 sand roller and 3 iron rollers & Small-sized private enterprise \\
\hline Jiangsu 1 & Japonica & 1 sand roller and 4 iron rollers & Large-sized private enterprise \\
\hline Jiangsu 2 & Indica hybrid & 1 sand roller and 2 iron rollers & Small-sized private enterprise \\
\hline Jiangxi 1 & Early Indica & 1 sand roller and 3 iron rollers & Large state-owned enterprise \\
\hline Jiangxi 2 & Early Indica preboiled rice & 1 sand roller and 3 iron rollers & Large state-owned enterprise \\
\hline Jiangxi 3 & Early Indica & 1 sand roller and 2 iron rollers & Large state-owned enterprise \\
\hline Liaoning & Japonica & 1 sand roller and 4 iron rollers & Medium-sized private enterprise \\
\hline Sichuan & Half Japonica rice and half Indica & 3 iron rollers & Medium-sized private enterprise \\
\hline Hunan 1 & Early Indica & 1 sand roller and 2 iron rollers & Medium-sized private enterprise \\
\hline Hunan 2 & Late Indica & 3 iron rollers & Large state-owned enterprise \\
\hline
\end{tabular}

${ }^{1}$ A sand roller mills a thick layer of bran with a rough surface of white rice; An iron roller mills a thin layer of bran with a smooth surface of white rice. 
Table 2. Analyzed chemical composition of the 17 rice bran samples used in experiment 1 ( $\%$ DM basis)

\begin{tabular}{|c|c|c|c|c|c|c|c|c|}
\hline Province & Crude protein & $\mathrm{AEE}$ & Starch & $\mathrm{NDF}$ & $\mathrm{ADF}$ & Ash & Calcium & Phosphorus \\
\hline Anhui 1 & 13.42 & 15.19 & 36.44 & 22.31 & 8.73 & 6.22 & 0.13 & 1.28 \\
\hline Anhui 2 & 14.48 & 16.60 & 40.53 & 19.29 & 7.32 & 7.27 & 0.13 & 1.60 \\
\hline Anhui 3 & 15.80 & 20.46 & 25.82 & 24.44 & 7.96 & 9.68 & 0.12 & 2.14 \\
\hline Guangxi & 13.97 & 18.97 & 38.35 & 26.36 & 7.59 & 6.69 & 0.19 & 1.52 \\
\hline Henan & 14.76 & 20.23 & 29.47 & 22.26 & 7.77 & 8.54 & 0.06 & 1.85 \\
\hline Hubei 1 & 15.63 & 19.59 & 33.00 & 27.30 & 7.96 & 7.09 & 0.11 & 1.57 \\
\hline Hubei 2 & 15.16 & 20.23 & 26.65 & 29.04 & 10.20 & 9.32 & 0.14 & 1.91 \\
\hline Heilongjiang 1 & 15.61 & 23.14 & 19.16 & 29.13 & 10.69 & 9.61 & 0.15 & 2.05 \\
\hline Heilongjiang 2 & 13.46 & 16.25 & 32.96 & 24.39 & 8.35 & 8.56 & 0.10 & 1.78 \\
\hline Jilin & 14.21 & 18.81 & 31.64 & 27.02 & 8.80 & 7.62 & 0.18 & 1.59 \\
\hline Jiangsu 1 & 16.20 & 16.95 & 24.96 & 29.44 & 11.77 & 8.36 & 0.13 & 1.63 \\
\hline Jiangsu 2 & 12.99 & 13.54 & 23.98 & 33.90 & 14.54 & 7.96 & 0.16 & 1.27 \\
\hline Jiangxi 1 & 13.89 & 17.54 & 36.56 & 27.16 & 8.38 & 8.22 & 0.15 & 1.72 \\
\hline Jiangxi 2 & 14.73 & 25.21 & 15.72 & 32.67 & 11.04 & 8.24 & 0.21 & 1.69 \\
\hline Jiangxi 3 & 14.53 & 19.30 & 29.62 & 22.10 & 7.64 & 8.33 & 0.15 & 1.81 \\
\hline Liaoning & 14.34 & 17.98 & 26.98 & 22.67 & 7.68 & 7.78 & 0.17 & 1.66 \\
\hline Sichuan & 15.76 & 19.51 & 26.85 & 23.68 & 7.95 & 8.91 & 0.10 & 2.03 \\
\hline Min & 12.99 & 13.54 & 15.72 & 19.29 & 7.32 & 6.22 & 0.06 & 1.27 \\
\hline Max & 16.20 & 25.21 & 40.53 & 33.90 & 14.54 & 9.68 & 0.21 & 2.14 \\
\hline Mean & 14.64 & 18.79 & 29.33 & 26.07 & 9.08 & 8.14 & 0.14 & 1.71 \\
\hline SD & 0.94 & 2.81 & 6.66 & 3.96 & 1.95 & 0.97 & 0.04 & 0.24 \\
\hline $\mathrm{CV}$ & 6.42 & 14.93 & 22.69 & 15.20 & 21.48 & 11.92 & 26.48 & 14.14 \\
\hline
\end{tabular}

DM, dry matter; AEE, acid hydrolyzed ether extract; NDF, neutral detergent fiber; ADF, acid detergent fiber; SD, standard deviation; CV, coefficient of variation.

diets. In Exp. 2, two additional rice bran samples were measured to verify the prediction equations developed. A control diet and two rice bran diets were fed to 18 growing barrows $(34.6 \pm 3.5 \mathrm{~kg})$. The control and experimental diets formulations were the same as diet in Exp. 1.

All ingredients were ground through a $2.5-\mathrm{mm}$ screen with a hammer mill. The diets formulation and nutrient levels were shown in Table 3 and 4. Vitamins and minerals

Table 3. Ingredient composition of experimental diets used in experiments 1 and 2 (\% as-fed)

\begin{tabular}{|c|c|c|}
\hline Ingredient & Basal diet & $\begin{array}{c}\text { Rice bran } \\
\text { diets }\end{array}$ \\
\hline Corn & 74.43 & 52.10 \\
\hline Soybean meal & 22.91 & 16.04 \\
\hline Rice bran & - & 29.20 \\
\hline Dicalcium phosphate & 0.90 & 0.90 \\
\hline Limestone & 0.90 & 0.90 \\
\hline Salt & 0.30 & 0.30 \\
\hline Choline chloride & 0.06 & 0.06 \\
\hline Vitamin and micromineral premix ${ }^{1}$ & 0.50 & 0.50 \\
\hline \multicolumn{3}{|c|}{$\begin{array}{l}\text { I Premix provided the following per kg of complete diet for growing pigs: } \\
\text { vitamin } \mathrm{A}, 5,512 \mathrm{IU} \text {; vitamin } \mathrm{D}_{3}, 2,200 \mathrm{IU} \text {; vitamin E, } 30 \mathrm{IU} \text {; vitamin } \mathrm{K}_{3} \text {, } \\
2.2 \mathrm{mg} \text {; vitamin } \mathrm{B}_{12}, 27.6 \mu \mathrm{g} \text {; riboflavin, } 4 \mathrm{mg} \text {; pantothenic acid, } 14 \mathrm{mg} \text {; } \\
\text { niacin, } 30 \mathrm{mg} \text {; choline chloride, } 400 \mathrm{mg} \text {; folacin, } 0.7 \mathrm{mg} \text {; thiamin } 1.5 \\
\mathrm{mg} \text {; pyridoxine } 3 \mathrm{mg} \text {; biotin, } 44 \mu \mathrm{g} \text {; } \mathrm{Mn}, 40 \mathrm{mg}(\mathrm{MnO}) ; \mathrm{Fe}, 75 \mathrm{mg} \\
\left(\mathrm{FeSO} \mathrm{H}_{4} \cdot \mathrm{H}_{2} \mathrm{O}\right) ; \mathrm{Zn}, 75 \mathrm{mg}(\mathrm{ZnO}) ; \mathrm{Cu}, 100 \mathrm{mg}\left(\mathrm{CuSO}_{4} \cdot 5 \mathrm{H}_{2} \mathrm{O}\right) ; \mathrm{I}, 0.3 \mathrm{mg} \\
(\mathrm{KI}) ; \mathrm{Se}, 0.3 \mathrm{mg}\left(\mathrm{Na}_{2} \mathrm{SeO}_{3}\right) \text {. }\end{array}$} \\
\hline
\end{tabular}

were supplemented in all diets at the same level to meet the estimated nutrient requirements for growing pigs recommended by the National Research Council (2012).

\section{Sample collection}

Each experiment consisted of a $7 \mathrm{~d}$ adaptation period followed by a $5 \mathrm{~d}$ total collection of feces and urine. Feces and urine collection was conducted according to the methods described by Song et al. (2003) and Ren et al. (2011). Feces were collected, sealed in plastic bags and stored at $-18^{\circ} \mathrm{C}$. Urine was collected into plastic buckets containing $50 \mathrm{~mL}$ of $6 \mathrm{~N} \mathrm{HCl}$ and emptied each afternoon. The collected urine was weighed and $10 \%$ of the daily urinary excretion was stored at $-18^{\circ} \mathrm{C}$. At the end of $5 \mathrm{~d}$ total collection period, all the feces and urine collected during the experiment were thawed and mixed within animal and diet, and a representative sub-sample was obtained for chemical analysis. Before analysis, fecal subsamples were dried for $72 \mathrm{~h}$ at $65^{\circ} \mathrm{C}$ in an oven, ground through a $1-\mathrm{mm}$ screen and mixed thoroughly.

\section{Chemical analyses}

Dry matter (DM), crude protein $(\mathrm{CP})$, neutral detergent fiber (NDF), acid detergent fiber (ADF), ash, calcium and phosphorus content in the diets and rice bran samples were analyzed according to the procedures of the Association of Official Analytical Chemists (AOAC, 2000). Acid 
Table 4. Chemical composition of experiment 1 diets (DM basis)

\begin{tabular}{|c|c|c|c|c|c|c|c|c|c|}
\hline \multirow{2}{*}{ Items } & \multirow{2}{*}{$\begin{array}{l}\text { Gross energy } \\
(\mathrm{MJ} / \mathrm{kg})\end{array}$} & \multicolumn{8}{|c|}{ Composition (\%) } \\
\hline & & Crude protein & AEE & Starch & NDF & $\mathrm{ADF}$ & Ash & Calcium & Phosphorus \\
\hline Basal diet $^{1}$ & 18.31 & 14.56 & 3.10 & 49.49 & 8.86 & 3.91 & 4.01 & 0.64 & 0.50 \\
\hline \multicolumn{10}{|l|}{ Rice bran diets } \\
\hline Anhui 1 & 18.96 & 14.97 & 6.57 & 43.82 & 12.88 & 5.47 & 5.28 & 0.66 & 0.78 \\
\hline Anhui 2 & 18.70 & 15.28 & 6.98 & 45.01 & 12.00 & 5.06 & 5.59 & 0.66 & 0.88 \\
\hline Anhui 3 & 19.05 & 15.67 & 8.11 & 40.72 & 13.50 & 5.25 & 6.29 & 0.66 & 1.03 \\
\hline Guangxi & 19.06 & 15.13 & 7.67 & 44.37 & 14.06 & 5.14 & 5.42 & 0.68 & 0.85 \\
\hline Henan & 19.12 & 15.37 & 8.04 & 41.78 & 12.86 & 5.19 & 5.96 & 0.64 & 0.95 \\
\hline Hubei 1 & 19.17 & 15.62 & 7.85 & 42.81 & 14.33 & 5.25 & 5.54 & 0.65 & 0.87 \\
\hline Hubei 2 & 19.17 & 15.48 & 8.04 & 40.96 & 14.84 & 5.90 & 6.19 & 0.66 & 0.96 \\
\hline Heilongjiang 1 & 19.09 & 15.61 & 8.89 & 38.77 & 14.87 & 6.04 & 6.27 & 0.66 & 1.01 \\
\hline Heilongjiang 2 & 18.90 & 14.99 & 6.88 & 42.80 & 13.48 & 5.36 & 5.96 & 0.65 & 0.93 \\
\hline Jilin & 19.07 & 15.20 & 7.63 & 42.42 & 14.25 & 5.49 & 5.69 & 0.67 & 0.87 \\
\hline Jiangsu 1 & 19.04 & 15.79 & 7.08 & 40.46 & 14.96 & 6.36 & 5.91 & 0.66 & 0.88 \\
\hline Jiangsu 2 & 18.98 & 14.85 & 6.09 & 40.18 & 16.26 & 7.17 & 5.79 & 0.67 & 0.78 \\
\hline Jiangxi 1 & 18.80 & 15.11 & 7.26 & 43.85 & 14.29 & 5.37 & 5.87 & 0.66 & 0.91 \\
\hline Jiangxi 2 & 18.95 & 15.36 & 9.50 & 37.77 & 15.90 & 6.15 & 5.87 & 0.68 & 0.90 \\
\hline Jiangxi 3 & 18.97 & 15.30 & 7.77 & 41.83 & 12.81 & 5.15 & 5.90 & 0.67 & 0.94 \\
\hline Liaoning & 19.05 & 15.24 & 7.38 & 41.05 & 12.98 & 5.16 & 5.74 & 0.67 & 0.89 \\
\hline Sichuan & 19.14 & 15.66 & 7.83 & 41.02 & 13.28 & 5.24 & 6.07 & 0.65 & 1.00 \\
\hline
\end{tabular}

DM, dry matter; AEE, acid hydrolyzed ether extract; NDF, neutral detergent fiber; ADF, acid detergent fiber.

${ }^{1}$ Analysis conducted in duplicate

hydrolyzed ether extract (AEE) was determined by acid hydrolysis using 3 N HCL (Sanderson, 1986) followed by crude fat extraction with petroleum ether (AOAC, 2005) using an Extraction System (Extractor, Ankom Technology, Macedon, NY, USA). The gross energy (GE) of feces, urine, diets and rice bran samples were measured by an automatic adiabatic oxygen bomb calorimeter (Parr 6300 Calorimeter, Moline, IL, USA) with benzoic acid as a standard. Before the GE of urine was measured, a $4 \mathrm{~mL}$ sample of urine was injected onto 2 filter papers in a special crucible, and dried for $8 \mathrm{~h}$ in a $65^{\circ} \mathrm{C}$ drying oven. The starch content was determined after converting starch to glucose using an enzyme assay kit (Megazym International Ireland, Wicklow, Ireland).

\section{Calculations}

The DE and ME content contributed by each rice bran sample was calculated according to the difference method (Adeola, 2001). The energy lost in feces and urine was determined for each treatment. The DE in each diet was calculated from the difference between GE in the diet and GE excreted in the feces. The ME in each diet was calculated by subtracting the energy losses in urine from DE in each diet. The DE and ME used in the calculation were apparent measurement because the endogenous losses of energy and nutrients were not accounted for (Sauvant et al., 2004).

\section{Statistical analysis}

Data were analyzed by SPSS 20 (SPSS Statistics 20, Rel. 20.0.0. 2012. Chicago: SPSS Inc., IL, USA) using pig as the experimental unit. The equations for predicting the DE and ME from chemical composition were obtained using the stepwise regression procedure of SPSS 20. The equations with the smallest residual standard deviation were presented in the results.

\section{RESULTS}

\section{Chemical composition of rice bran}

It was clear that the samples varied widely in chemical composition (Table 2). The AEE concentration in rice bran ranged from $13.54 \%$ to $25.21 \%$ (mean $18.79 \%$ ), the coefficient variation (CV) of AEE was $14.93 \%$ and $\mathrm{CP}$ ranged from $12.99 \%$ to $16.20 \%$ (mean $14.64 \%$, CV $6.42 \%$ ), while the content of starch in the samples ranged from $15.72 \%$ to $40.53 \%$ (mean $29.33 \%$, CV $22.69 \%$ ). The NDF ranged from $19.29 \%$ to $33.90 \%$ (mean $26.07 \%$, CV $15.20 \%$ ) and ADF ranged from $7.32 \%$ to $14.54 \%$ (mean $9.08 \%, \mathrm{CV} 21.48 \%$ ). The coefficient of variation of AEE, $\mathrm{NDF}$, ash, phosphorus were greater than $10 \%$, while the coefficient of variation for starch, ADF and calcium were above $20 \%$.

Energy content and the energy digestibility of rice bran The DE and ME of rice bran ranged from 14.48 to 16.85 
(mean 15.84, MJ/kg) and 12.49 to 15.84 (mean 14.31, $\mathrm{MJ} / \mathrm{kg}$ ) of $\mathrm{DM}$, respectively. The ratio of $\mathrm{ME}$ to $\mathrm{DE}$ calculated from the 17 rice bran samples ranged from $84.49 \%$ to $96.00 \%$, with a mean value of $90.32 \%$ (Table 6). The mean DE and ME of five Japonica rice bran samples was 15.20 and 13.70, respectively. The mean DE and ME of eight Indica rice bran samples was 16.04 and 14.48, respectively. The mean DE of Indica rice bran was greater than Japonica rice bran $(\mathrm{p}<0.05)$. The results were not shown.

Correlation coefficients between chemical composition and energy content of rice bran

There were positive correlations $(\mathrm{p}<0.01)$ between AEE, $\mathrm{CP}$ and GE, DE, and ME, respectively. Starch had a negative correlation $(\mathrm{p}<0.01)$ with AEE, NDF, ADF, and ash, respectively. There were positive correlations $(p<0.01)$ between AEE and CP, NDF, and ADF (Table 5).

\section{Prediction of the energy content of rice bran}

The DE and ME content were predicted from the chemical composition of rice bran (Table 8). Some equations based on a single chemical characteristic showed a highly linear correlation. The AEE was the best predictor of $\mathrm{DE}$ content $\left(\mathrm{R}^{2}=0.69, \mathrm{p}<0.01, \mathrm{MJ} / \mathrm{kg}\right.$ of $\left.\mathrm{DM}\right)$ in rice bran. Multiple linear regression analyses were conducted to develop prediction equations for DE and ME content of rice bran based on the results of a step-wise regression analysis (Table 8). The DE and ME models were established using AEE, CP, starch, NDF, ADF as predictors. The recommended equation for $\mathrm{DE}$ was $\mathrm{DE}(\mathrm{MJ} / \mathrm{kg}$ of $\mathrm{DM})=$ $8.81+(0.18 \times \mathrm{CP}[\%$ of $\mathrm{DM}])+(0.21 \times \mathrm{AEE}[\%$ of $\mathrm{DM}])+(0.01 \times$ starch $[\%$ of $\mathrm{DM}])\left(\mathrm{R}^{2}=0.73 ; \mathrm{p}<0.05\right)$. The recommended equation for $\mathrm{ME}$ was $\mathrm{ME}(\mathrm{MJ} / \mathrm{kg}$ of $\mathrm{DM})=6.22+(0.28$ $\times \mathrm{AEE}[\%$ of $\mathrm{DM}])+(0.22 \times \mathrm{CP}[\%$ of $\mathrm{DM}])+(0.02 \times \operatorname{starch}[\%$ of $\mathrm{DM}])-(0.14 \times \mathrm{NDF}[\%$ of $\mathrm{DM}])+(0.30 \times \mathrm{ADF}[\%$ of $\mathrm{DM}])$ $\left(\mathrm{R}^{2}=0.61 ; \mathrm{p}<0.05\right)$. Moreover, $\mathrm{DE}$ and $\mathrm{ME}$ content were highly correlated $\left(\mathrm{ME}=0.92 \times \mathrm{DE}+0.44 ; \mathrm{R}^{2}=0.96 ; \mathrm{p}<0.01\right.$, $\mathrm{MJ} / \mathrm{kg}$ of DM).

\section{Validation of the prediction equations of rice bran}

The values of DE in the verification samples from Exp. 2 were 16.07 and $16.00 \mathrm{MJ} / \mathrm{kg}$ (Table 7, Hunan 1 and 2). The recommended predicted value of DE content of Hunan 1 and 2 were both $16.06 \mathrm{MJ} / \mathrm{kg}$ (Table 8). The determined ME content of Hunan 1 and 2 were 15.53 and $15.43 \mathrm{MJ} / \mathrm{kg}$. The recommended predicted value of ME content of Hunan 1 and 2 were 15.59 and $15.06 \mathrm{MJ} / \mathrm{kg}$, respectively.

\section{DISCUSSION}

\section{Chemical composition variations}

The variations in the chemical composition of the rice bran used in the present study for indicators like CP (12.99\% to $16.20 \%$ of DM), AEE (13.54\% to $25.21 \%$ of DM) and starch (15.72\% to $40.53 \%$ of DM), were similar to previous data, which showed variation in $\mathrm{CP}(13.4 \%$ to $17.3 \%$ of DM), EE (12.3\% to $20.2 \%$ of DM), starch $(22.2 \%$ to $56.4 \%$ of DM) by Houston (1972), Barber (1980), Warren and Farrell (1990). The content of NDF in the current experiment ranged from $19.29 \%$ to $33.90 \%$ of DM which was wider than previous data ranging from $20.1 \%$ to 29.2\% (Warren and Farrell, 1990) and $25.5 \%$ to $34.3 \%$ (Kaufmann et al., 2005). The values of CP, EE, starch, NDF,

Table 5. Correlation coefficients $(r)$ between chemical characteristics and energy content of the 17 rice bran samples $(N=17)$

\begin{tabular}{|c|c|c|c|c|c|c|c|c|c|c|c|c|}
\hline Item & $\mathrm{DE}$ & ME & $\begin{array}{l}\text { Gross } \\
\text { energy }\end{array}$ & $\begin{array}{l}\text { Crude } \\
\text { protein }\end{array}$ & AEE & Starch & NDF & $\mathrm{ADF}$ & Ash & Calcium & Phosphorus & ME:DE \\
\hline$\overline{\mathrm{DE}}$ & 1.00 & & & & & & & & & & & \\
\hline ME & $0.86^{*}$ & & & & & & & & & & & \\
\hline Gross energy & $0.45^{*}$ & 0.41 & & & & & & & & & & \\
\hline Crude protein & $0.60 *$ & $0.58 *$ & $0.62 *$ & & & & & & & & & \\
\hline $\mathrm{AEE}$ & $0.83 *$ & $0.71 *$ & $0.70^{*}$ & $0.56^{*}$ & & & & & & & & \\
\hline Starch & -0.41 & $-0.42 *$ & $-0.55^{*}$ & -0.40 & $-0.56^{*}$ & & & & & & & \\
\hline NDF & -0.07 & $0.00 *$ & 0.34 & 0.02 & 0.20 & $-0.61^{*}$ & & & & & & \\
\hline $\mathrm{ADF}$ & -0.25 & -0.10 & 0.08 & -0.09 & -0.11 & $-0.61 *$ & $0.85^{*}$ & & & & & \\
\hline Ash & $0.67 *$ & $0.58 *$ & 0.33 & $0.52 *$ & $0.46^{*}$ & $-0.63^{*}$ & 0.21 & 0.20 & & & & \\
\hline Calcuim & -0.12 & -0.19 & 0.19 & -0.25 & 0.24 & -0.20 & $0.44 *$ & 0.25 & -0.25 & & & \\
\hline Phosphorus & $0.85 *$ & $0.69 *$ & 0.41 & $0.65 *$ & $0.62 *$ & -0.37 & -0.16 & -0.29 & $0.86^{*}$ & -0.30 & & \\
\hline ME:DE & 0.15 & $0.62 *$ & 0.12 & 0.23 & 0.10 & -0.20 & 0.12 & 0.19 & 0.13 & -0.18 & 0.05 & \\
\hline $\begin{array}{l}\text { Number } \\
\text { of rollers }{ }^{1}\end{array}$ & $-0.41^{*}$ & -0.23 & -0.14 & -0.03 & -0.14 & 0.02 & 0.05 & 0.09 & -0.34 & 0.20 & -0.36 & 0.19 \\
\hline
\end{tabular}

DE, digestible energy; ME, metabolizable energy; AEE, acid hydrolyzed ether extract; NDF, neutral detergent fiber; ADF, acid detergent fiber.

${ }^{1}$ A roller is the core part of milling machine, and a roller is used to mill a layer of bran from rice. Usually, there are 2 to 5 rollers in a milling production line.

* Means $\mathrm{p}<0.05$ 
Table 6. The energy content of 17 diets and rice brans used in experiment $1(\mathrm{MJ} / \mathrm{kg} \mathrm{DM}$ basis)

\begin{tabular}{|c|c|c|c|c|c|}
\hline Item & $\mathrm{DE}^{1}$ of diet & ME of diet & DE of rice bran & ME of rice bran & $\mathrm{ME} / \mathrm{DE}$ of rice bran \\
\hline Anhui 1 & 15.92 & 15.32 & 14.49 & 12.49 & 86.16 \\
\hline Anhui 2 & 16.23 & 15.73 & 16.00 & 14.33 & 89.58 \\
\hline Anhui 3 & 16.43 & 15.66 & 16.71 & 14.11 & 84.49 \\
\hline Guangxi & 15.92 & 15.53 & 15.53 & 14.23 & 91.65 \\
\hline Henan & 16.47 & 16.23 & 16.63 & 15.84 & 95.26 \\
\hline Hubei 1 & 16.03 & 15.51 & 15.49 & 13.78 & 88.97 \\
\hline Hubei 2 & 16.27 & 15.84 & 16.36 & 14.92 & 91.20 \\
\hline Heilongjiang 1 & 16.31 & 15.80 & 16.76 & 15.05 & 89.76 \\
\hline Heilongjiang 2 & 16.24 & 15.79 & 15.53 & 14.04 & 90.39 \\
\hline Jilin & 16.17 & 15.61 & 15.69 & 13.83 & 88.14 \\
\hline Jiangsu 1 & 16.12 & 15.94 & 15.21 & 14.60 & 96.00 \\
\hline Jiangsu 2 & 15.82 & 15.39 & 14.48 & 13.05 & 90.12 \\
\hline Jiangxi 1 & 16.00 & 15.48 & 15.49 & 13.76 & 88.83 \\
\hline Jiangxi 2 & 16.10 & 15.65 & 16.85 & 15.37 & 91.24 \\
\hline Jiangxi 3 & 16.19 & 15.81 & 16.12 & 14.84 & 92.01 \\
\hline Liaoning & 15.83 & 15.37 & 15.08 & 13.54 & 89.82 \\
\hline Sichuan & 16.50 & 16.09 & 16.82 & 15.46 & 91.88 \\
\hline Min & 15.82 & 15.32 & 14.48 & 12.49 & 84.49 \\
\hline Max & 16.50 & 16.23 & 16.85 & 15.84 & 96.00 \\
\hline Mean & 16.15 & 15.69 & 15.84 & 14.31 & 90.32 \\
\hline SD & 0.21 & 0.25 & 0.78 & 0.88 & 2.81 \\
\hline $\mathrm{CV}$ & 1.31 & 1.61 & 4.91 & 6.17 & 3.11 \\
\hline
\end{tabular}

DM, dry matter; DE, digestible energy; ME, metabolizable energy; SD, standard deviation; $\mathrm{CV}$, coefficient of variation $(\mathrm{N}=6)$.

${ }^{1}$ Energy content of nice brans determined from the diets using the difference method.

and $\mathrm{ADF}$ were $15.11 \%, 13.77 \%, 27.00 \%, 26.28 \%$, and $11.87 \%$ from the National Research Council (2012) and $12.8 \%, 16.5 \%, 27.4 \%, 22.9 \%$, and $13.4 \%$ from the Chinese Feed Database (2012) on a DM basis, respectively. These mean values were within the range obtained in the present study.

The variations can be explained by the following factors. Firstly, rice bran from Indica rice had higher CP, AEE, starch than those rice bran from Japonica rice from the same province, milling method and enterprise (Rice bran samples Anhui 1 and 2 in Tables 1 and 2). Secondly, different milling methods resulted in different chemical composition. A roller was the core part of the milling machine, and usually can be used to mill a layer of bran from rice. In most cases, there were 2 to 5 rollers in one milling production line depending on different production process. Samples produced with fewer rollers had higher $\mathrm{AEE}$ and $\mathrm{CP}$ with the same variety, province and enterprise (Rice bran samples Jiangxi 1 and 3 in Tables 1 and 2). Thirdly, different provinces provided different CP, AEE, and starch with the same variety and milling method (Rice bran samples Anhui 1 and Heilongjiang 1 in Tables 1 and 2). In addition, different soil, years and climate resulted in different chemical composition of rice bran (Zhou et al., 2006).

\section{Energy digestibility}

The DE and ME of rice bran were 14.11 and 13.64

Table 7. Chemical composition and energy value of the verification rice bran samples used in experiment 2 (\% DM basis)

\begin{tabular}{lcccccccccc}
\hline Item & $\begin{array}{c}\text { Crude } \\
\text { protein }\end{array}$ & AEE & Starch & NDF & ADF & Ash & Calcium & Phosphorus $\frac{\text { Energy content (MJ/kg) }}{\text { DE }}$ \\
\hline Ingredient & & & & & & & & & ME \\
$\quad$ Hunan 1 & 15.83 & 19.64 & 27.94 & 24.91 & 11.07 & 8.09 & 0.20 & 2.13 & $16.07^{2}$ & 15.53 \\
$\quad$ Hunan 2 & 16.33 & 19.08 & 30.32 & 27.58 & 10.54 & 6.94 & 0.18 & 1.89 & 16.00 & 15.43 \\
Diets & & & & & & & & & & 16.23 \\
$\quad$ Control diet & 14.64 & 3.10 & 49.49 & 8.79 & 3.89 & 3.96 & 0.63 & 0.49 & 16.02 \\
$\quad$ Hunan 1 diet & 15.78 & 7.86 & 41.34 & 13.57 & 6.13 & 5.78 & 0.68 & 1.02 & 16.22 & 15.95 \\
$\quad$ Hunan 2 diet & 15.92 & 7.70 & 42.03 & 14.35 & 5.97 & 5.45 & 0.67 & 0.95 & 16.09 & 15.80 \\
\hline
\end{tabular}

DM, dry matter; AEE, acid hydrolyzed ether extract; NDF, neutral detergent fiber; ADF, acid detergent fiber; DE, digestible energy; ME, metabolizable energy. 
Table 8. Prediction equations and validation of $\mathrm{DE}^{1}$ and $\mathrm{ME}$ equations developed from rice bran samples

\begin{tabular}{|c|c|c|c|c|c|c|c|c|}
\hline \multirow{2}{*}{$\begin{array}{l}\text { Equation } \\
\text { NO. }\end{array}$} & \multirow{2}{*}{ Equations } & \multirow{2}{*}{ RSD } & \multirow{2}{*}{$\mathrm{R}^{2}$} & \multirow{2}{*}{ p-value } & \multicolumn{2}{|c|}{ Hunan $1(\mathrm{MJ} / \mathrm{kg})$} & \multicolumn{2}{|c|}{ Hunan $2(\mathrm{MJ} / \mathrm{kg})$} \\
\hline & & & & & Predicted & Measured & Predicted & Measured \\
\hline$\overline{1}$ & $\mathrm{DE}=11.52+(0.23 \times \mathrm{AEE})$ & 0.45 & 0.69 & $<0.01$ & 16.04 & 16.07 & 15.91 & 16.00 \\
\hline 2 & $\begin{aligned} \mathrm{DE}= & 8.81+(0.18 \times \mathrm{CP})+(0.21 \times \mathrm{AEE}) \\
& +(0.01 \times \text { Starch })\end{aligned}$ & 0.45 & 0.73 & $<0.05$ & 16.06 & 16.07 & 16.06 & 16.00 \\
\hline 3 & $\begin{aligned} \mathrm{DE}= & 10.19+(0.13 \times \mathrm{CP})+(0.26 \times \mathrm{AEE}) \\
& +(0.01 \times \mathrm{Starch})-(0.10 \times \mathrm{NDF}) \\
& +(0.15 \times \mathrm{ADF})\end{aligned}$ & 0.44 & 0.79 & $<0.01$ & 16.80 & 16.07 & 16.33 & 16.00 \\
\hline 4 & $\begin{aligned} \mathrm{DE}= & 7.78-(0.09 \times \mathrm{CP})+(0.25 \times \mathrm{AEE}) \\
& +(0.05 \times \mathrm{Starch})-(0.08 \times \mathrm{NDF}) \\
& +(0.29 \times \mathrm{ADF})-(0.13 \times \mathrm{Ash}) \\
& -(1.8 \times \mathrm{Ca})+(2.43 \times \mathrm{P})\end{aligned}$ & 0.31 & 0.92 & $<0.01$ & 17.64 & 16.07 & 16.81 & 16.00 \\
\hline 5 & $\mathrm{ME}=10.13+(0.22 \times \mathrm{AEE})$ & 0.65 & 0.50 & $<0.01$ & 14.45 & 15.53 & 14.33 & 15.43 \\
\hline 6 & $\mathrm{ME}=7.30+(0.26 \times \mathrm{CP})+(0.17 \times \mathrm{AEE})$ & 0.63 & 0.55 & $<0.01$ & 14.75 & 15.53 & 14.79 & 15.43 \\
\hline 7 & $\begin{aligned} \mathrm{ME}= & 6.22+(0.22 \times \mathrm{CP})+(0.28 \times \mathrm{AEE}) \\
& +(0.02 \times \mathrm{Starch})-(0.14 \times \mathrm{NDF}) \\
& +(0.30 \times \mathrm{ADF})\end{aligned}$ & 0.66 & 0.61 & $<0.05$ & 15.59 & 15.53 & 15.06 & 15.43 \\
\hline 8 & $\begin{aligned} \mathrm{ME}= & 5.00+(0.04 \times \mathrm{CP})+(0.32 \times \mathrm{AEE}) \\
& +(0.05 \times \mathrm{Starch})-(0.11 \times \mathrm{NDF}) \\
& +(0.32 \times \mathrm{ADF})+(0.19 \times \mathrm{Ash}) \\
& -(5.56 \times \mathrm{Ca})+(0.23 \times \mathrm{P})\end{aligned}$ & 0.68 & 0.70 & 0.12 & 15.03 & 15.53 & 14.37 & 15.43 \\
\hline
\end{tabular}

DE, digestible energy (MJ/kg); ME, metabolizable energy (MJ/kg); RSD, the root mean square of the error that applies to the whole model; AEE, acid hydrolyzed ether extract (\%); CP, crude protein (\%); NDF, neutral detergent fiber (\%); ADF, acid detergent fiber (\%); Ca, calcium (\%); P, phosphorus (\%). $\mathrm{R}^{2}$ and $\mathrm{p}$-values are the evaluation of the corresponding regression coefficient.

$\mathrm{MJ} / \mathrm{kg}$ of DM published in the National Research Council (2012). The average DE and ME of rice bran determined in the present study was $15.84 \mathrm{MJ} / \mathrm{kg}$ and $14.31 \mathrm{MJ} / \mathrm{kg}$ of DM. These data were greater than National Research Council (2012). The DE of rice bran ranged from 14.48 to 16.85 $\mathrm{MJ} / \mathrm{kg}$ in the present study which were in agreed with the reported values of 16.24 (Robles and Ewan, 1982) and 14.11 (National Research Council, 2012) MJ/kg of DM, and greater than 11.68 (Nehring, 1970), 14.19 (Brooks and Lumanta, 1975), and $13.52 \mathrm{MJ} / \mathrm{kg}$ of DM (Campabadal et al., 1976). The ME of rice bran ranged from 12.49 to 15.84 $\mathrm{MJ} / \mathrm{kg}$ of DM in the present study, which covers the range of previously published values of 15.53 (Robles and Ewan, 1982) and 13.64 (National Research Council, 2012) MJ/kg of DM, but greater than the values of $11.09 \mathrm{MJ} / \mathrm{kg}$ of DM reported by Nehring (1970).

The difference between the minimum and maximum of $\mathrm{DE}$ and $\mathrm{ME}$ were 2.37 and $3.35 \mathrm{MJ} / \mathrm{kg}$ in the 17 rice bran samples, respectively. Great variation can result in considerable error if the average energy values were used in formulation. Therefore, dynamic comparisons and prediction equations were necessary in order to accurately predict the energy content of rice brans varying in chemical composition.

\section{Prediction of energy content in rice bran}

There can be great differences between the actual and predicted value of $\mathrm{DE}$ and $\mathrm{ME}$ in diets due to chemical variations. Correlation coefficients and prediction equations based on chemical composition clearly indicated that the AEE was the best predictor for DE and ME prediction equations. The higher the AEE content in rice bran, the higher the DE content. In the DE stepwise prediction equations, AEE, CP, starch, NDF, ADF, ash, calcium, and phosphorus came into the model successively. The more predictors which were included into the regressions, the better the determination coefficient (Table 8).

\section{The accuracy of the prediction equations}

The second equation in Table 7 most accurately predicted the DE energy content of the verification samples Hunan 1 and 2 (0.01 and $0.06 \mathrm{MJ} / \mathrm{kg}$ of DM). Furthermore, the seventh equation gave the smallest difference between predicted value and measured value of ME (0.06 and 0.37 $\mathrm{MJ} / \mathrm{kg}$ of DM). Both the fourth and eighth equations had the highest $\mathrm{R}$ square, but they were not the most accurate. The reason was because the more predictors involved, the possibility of errors in determination was greater. The first equation was not the best one due to its single predictor and lower R square (Table 8).

\section{CONCLUSIONS}

In summary, there was great variation in the chemical composition in rice bran due to different varieties, origin and milling methods. The DE and ME content among 17 rice bran samples ranged widely and were highly correlated with AEE. Therefore, the variation in chemical composition 
in rice bran has to be considered when estimating its energy value and formulating the diet. The DE and ME content of rice bran can be predicted accurately using prediction equations based on the chemical composition in rice bran.

\section{ACKNOWLEDGMENTS}

This research was financially supported by the Special Public Sector Fund in Agriculture (200903006).

\section{REFERENCES}

Adeola, O. 2001. Digestion and balance techniques in pigs. In: Swine Nutrition (Eds. A. J. Lewis and L. L. Southern). CRC Press, Washington, DC, USA. pp. 903-916.

AOAC International. 2000. Official Methods of Analysis. 17th ed. Association of Official Analytical Chemists Int., Arlington, VA, USA.

AOAC International. 2005. Official Methods of Analysis. 18th ed. Association of Official Analytical Chemists Int., Arlington, VA, USA.

Barber, S. and D. E. Barber. 1980. Rice bran: Chemistry and technology. In: Rice: Production and Utilization (Ed. B. S. Luh). AVI Publishing Company, Westport, CT, USA. pp. 790862.

Brooks, C. C. and I. G. Lumanta. 1975. Rice bran composition and digestibility by the pig. Proc. Western Sec. Amer. Soc. Anim. Sci. 27:112-114.

Campabadal, C., D. Creswell, H. D. Wallace, and G. E. Combs. 1976. Nutritional value of rice bran for pigs. Trop. Agri. 53:141-149.

Chris C., K. Parker, J. Parker, R. N. Sayre, and R. M. Saunders. 1985. Rice bran in swine rations. California Agriculture 56:19-20.

David, J. F. 1994. Utilization of rice bran in diets for domestic fowl and ducklings. World's Poult. Sci. J. 50:115-131.

Houston, D. F. 1972. Rice bran and polish. In: Rice Chemistry and Technology (Ed. D. F. Houston). American Association of Cereal Chemists, St. Paul, MN, USA. pp. 272-275.

Hussein, A. S. and F. H. Kratzer. 1982. Effect of rancidity on the feeding value of rice bran for chickens. Poult. Sci. 61:24502455 .
Kaufmann, C., W. C. Sauer, M. Cervantes, Y. Zhang, J. He, M. Rademacher, and J. K. Htoo. 2005. Amino acid and energy digestibility in different sources of rice bran for growing pigs. Can. J. Anim. Sci. 85: 355-363.

Majun, G. K. and C. G. Payne. 1977. Autoclaved rice bran in layers' diets. Br. Poult. Sci. 18:201-203.

Nehring, K. 1970. Futtermitteltabellenwerk. Dt. Landw. Verlag, Berlin, Germany.

National Research Council. 2012. Nutrient Requirements of Swine. 11th rev. ed. National Academy Press, Washington, DC, USA.

Ren, P., Z. P. Zhu, B. Dong, J. J. Zang, and L. M. Gong. 2011. Determination of energy and amino acid digestibility in growing pigs fed corn distillers' dried grains with solubles containing different lipid levels. Arch. Anim. Nutr. 65:303-319.

Robles, A. and R. C. Ewan. 1982. Utilization of energy of rice and rice bran by young pigs. J. Anim. Sci. 55:572-577.

Sanderson, P. 1986. A new method of analysis of feeding stuffs for the determination of crude oils and fats In: Recent Advances in Animal Nutrition (Eds. W. Haresign and D. J. A. Cole). Butterworths, London, UK. pp. 77-81.

Saunders, R. M. 1990. The properties of rice bran as a foodstuff. Cereal Food World 35:632, 634-636.

Sauvant, D., J. M. Perez, and G. Tran. 2004. Tables of Composition and Nutritional Value of Feed Materials: Pig, poultry, sheep, goats, rabbits, horses, and fish (Eds. D. Sauvant, J. M. Perez, and G. Tran). Netherlands and INRA. Paris, France. pp. 304-309.

Sayre, R. N., L. Earl, F. H. Kratzer, and R. M. Saunders. 1987. Nutritional qualities of stabilized and raw rice bran for chicks. Poult. Sci. 66:493-499.

Serra, A., Z. B. Johnson, J. Smith, and P. Noland. 1983. Processing rice bran for pigs. Ark. Farm Res. 32: 12.

Song, G. L., D. F. Li, X. S. Piao, F. Chi, and W. J. Yang. 2003. Apparent ileal digestibility of amino acids and the digestible and metabolizable energy content of high-oil corn varieties and its effects on growth performance of pigs. Arch. Anim. Nutr. 57:297-306.

Warren, B. E. and D. J. Farrell. 1990. The nutritive value of fullfat and defatted Australian rice bran. II. Growth studies with chickens, rats and pigs. Anim. Feed Sci. Technol. 27:229-246.

Zhou, Y. B., Q. Zhang, and T. M. Li. 2006. Relationship between ingredient of rice bran and whitening degree of rice. Cereal Feed Industry 1:10-12. 